\title{
Development and Identity of Guatemalan Refugee Children in Mexico: Conditions and Options for Support Interventions
}

\author{
Inda Sáenz-Romero and Juan José Sánchez-Sosa
}

\begin{abstract}
The study describes current conditions of Guatemalan refugee children living in shelter camps in the Mexican southeastern states of Chiapas, Campeche and Quintana-Roo. Aspects of children's refugee life in Mexico City are also described. Analysis includes historic and contextual aspects of Guatemalan refuge in Mexico since the eighties: counter-insurgent wars, fleeing, arrival in Mexico, psychosocial and traumatic experiences, problems and expectations emerging from the prospect of returning to Guatemala and consequences of the Chiapas armed conflict. More specifically, the study analyses such issues as health and nutrition, and especially education. Analyses compare the camps' school systems and additional support actions based on training programs for "community promoters." Trainees are both adults and children, and program activities include the promotion of cultural identity, therapeutic work on traumatic experiences, coping with the challenge of returning to Guatemala en masse, and treating or preventing other psychological complaints.
\end{abstract}

\section{Précis}

Cette étude décrit les conditions de vie actuelles d'enfants réfugiés guatémaltèques vivant dans des camps de refuge aménagés dans les états du sud-est mexicain du Chiapas, de Campeche et de Quintina-Roo. Certains aspects de la vie des enfants réfugiés à Mexico sont aussi décrits. La présente analyse inclut une présentation des aspects historiques et une mise en perspective de la vie des réfugiés guatémaltèques au Mexique depuis les années 1980: les guerres anti-

Inda Sáenz-Romero and Juan José Sánchez-Sosa are researchers and scholars at the School of Psychology, National Autonomous University of Mexico (UNAM). ${ }^{1}$ insurectionnelles, la fuite, l'arrivée au Mexique, l'expérience du traumatisme psychosocial, les problèmes et les attentes résultant de la perspective d'un retour au Guatémala, les conséquences du conflit armé du Chiapas. Plus spécifiquement, la présente étude analyse les questions suivantes: santé, nutrition, et surtoutéducation. L'analyse établit une comparaison entre les systèmes scolaires des différents camps et entre les différentes interventions de soutien basées sur des programmes éducatifs ciblant les "promoteurs communautaires". Les bénéficiaires de ces programmes particuliers sont des adultes et des enfants, et les activités de ces programmes comprennent la promotion de l'identité culturelle, le travail thérapeutique sur des expériences traumatiques, la démarche consistant à faire face au défi d'un retour massifau Guatémala, le traitement et la prévention d'autres désordres psychologiques.

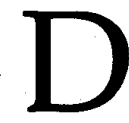
uring the period between 1975 and 1985 the counter-insur gent military operations in Guatemala virtually levelled hundreds of villages. Thousands of children became orphans and massive population displacements occurred both within and outside the Guatemalan borders. Numerous accounts, testimonies, sociopolitical studies and doctoral dissertations documented the atmosphere produced by political violence and severe human rights violations and the consequences for the Guatemalan population (Falla 1983; Simon 1987; Zur 1993).

During the worst part of this violent period between 1981 and 1982, estimates suggest that nearly 1.3 million people from El Quiche, Chimaltenango and Alta Verapaz, i.e. 80 percent of the population from the Guatemalan high plateau, were forced to leave their homes temporarily or even permanently (Guatemala Health Rights Support Project 1992). The first wave of refugees crossed the border into Mexico in 1981 only to be immediately deported by the Mexican government. The international protests which followed, led the UNHCR to establish offices in the area after reaching an agreement with the government.

Mexico has a long-lasting tradition of sheltering political exiles. Under the protection of President Cárdenas, thousands of Spanish republicans found asylum in Mexico. In the seventies, after the establishment of dictatorships in South America and their "dirty war" against any opposition, thousands of exiles from Argentina, Chile and Uruguay, arrived in Mexico individually or in small groups.

The characteristics and conditions of Central American refugees are very different from those of previous exile immigrations. Guatemalans arrived in large numbers, most were Indian agricultural workers already living in poverty and had little or no schooling and many of them, especially women, did not speak Spanish.

A large proportion of this population lived in the mountains or in the jungle, awaiting the withdrawal of the army from their communities. Only after this did not happen for a prolonged period of time, did they decide to cross the border into Mexico. This produced an incoming refugee population with particularly poor states of health, nutrition and high levels of psychological trauma.

By the end of 1992, UNHCR recorded 46,000 Guatemalan refugees in 127 camp shelters along the Chiapas border, four camps in Campeche, and three in Quintana Roo. Additional accounts estimate that as many as 150,000 dispersed unidentified Guatemalan exiles were living along the southern border, in other towns and in 
Mexico City (Aguayo et al: 1989; Salvadó 1988).

Since then, repatriation initiatives have diminished the refugee population in Mexico. Currently, the number of identified exiles in Mexico's southeast region is nearly 39,000 of which some 50 percent are children already born in Mexico (Table 1).

The unidentified dispersed exile population is difficult to study due to their illegal status. Some studies are carried out when small groups of this population seek services from the UNHCR or other nongovernmental organizations (NGO's). Such studies usually reveal these individuals' gruelling living conditions and high levels of stress (Botinelli, Maldonado, Troya, Herrera \& Rodríguez 1990; O'Dogherty 1991; Sáenz 1992/93; López 1994). In order to conceal their origin and avoid deportation, parents teach their children to adopt customs and accents or even to make up stories in order to appear to be from Oaxaca or Chiapas. Often they change their names depending on who they talk to, and many children do not attend school due to the lack of a birth certificate.

During the last fifteen years, however, many of these dispersed refugees have managed to legalize their status and have participated in educational and cultural programs for women, children and the elderly, organized by several NGOs (Harrington 1994; López 1994; Miller \& Billings 1994). The Mexican government, the Mexican Commission for Refugee Assistance (COMAR), the UNHCR and several NGO's have collaborated in developing and implementing programs for refugee populations. They have been assigned leased land for both housing and agriculture; they have been provided with food quotas, infrastructure support, health and education services, especially in the shelter camps called "safe settlements" in Campeche and Quintana Roo (Didier 1985).

These programs, however, are of little help to cope with the sense of vulnerability and defencelessness of these populations (Manz 1987;Salvadó1988,

Aguayo et al. 1989; Farías \& Billings 1993; Farías 1994; Sáenz 1994). Many refugees suffered one or more traumatic events either as personal victims or as witnesses of severe human rights violations (Melville \& Lykes 1992; Botinelli, et al. 1990; Del Huerto 1986). Post-Traumatic Stress Disorder (PTSD), psychosomatic complaints, depression and anxiety, are common

Table 1: Number of Guatemalan Refugees Living in Mexico

\begin{tabular}{lcc}
\hline Settling site & Number of camps & Number of persons \\
\hline Chiapas & 113 & 18,118 \\
Campeche & 4 & 9,846 \\
Quintana Roo & 3 & $3,962^{*}$ \\
Dispersed & & 6,711 \\
Total identified Guatemalan & \\
refugees in Mexico & 38,637 \\
\hline *-17 year old children. & \\
Source: UNHCR, April, 1996. & \\
\hline
\end{tabular}

among these individuals. Some symptoms keep affecting the victims long after the traumatic episodes and massive losses occurred (Sáenz 1994). A high prevalence of these disorders has also been found in refugee populations and torture victims elsewhere in the world (Deutsch, Hoffnung, Speyer, Varela \& Viñar 1991; Summerfield 1991).

The perspective of returning en masse to their land of origin in the next two years poses new organizational challenges. It produces conflicts inside families and communities which are separated or divided over the issue of whether to return to Guatemala or to assimilate to the host country. The most significant problems in this respect occur within the adolescent group. Many youngsters choose to marry Mexicans to avoid returning to their homeland; others simply abandon the camps and seek a job elsewhere. Adolescents reminisce about episodes of terror which occurred during their flight and often reject the option of returning home. Children must adapt to an unknown country which, depending on their parents' account, is perceived as either hell or paradise.

The Zapatista uprising in January of 1994 resulted in the deterioration the already precarious situation in the Chiapas refugee camps. Land which was lent to the refugees for settlement and cultivation by the Catholic church was invaded by other groups and the refugees mobility inside the state was

further restricted. The potential for subsistence decreased making them more dependent on international assistance (European Commission 1995).

\section{Psychosocial Status and Life Conditions of Refugee Children}

The health status of refugee children and their potential for development is mediated by their parents' health and psychosocial conditions (Farías \& Arana 1991; MacCallin 1991). A study analyzed data collected by refugee women of the Mama Maquin organization in Chiapas. The survey involved a sample of 867 refugee women of different ethnic backgrounds: Kanjobal, Mam, Chuj, Jacalteco and Castellano and revealed that 33 percent of the women spoke Mayan only; only 34 percent could read and write; and 66 percent had no schooling at all. 33 percent of the husbands abused alcohol and it was estimated that 12-23 percent of them were physically abusive towards their wives and 7-18 percent practiced polygamy. The average woman had four children and 60 percent of the children were already born 
in exile. Sevnty-eight percent of the children were malnourished and the child mortality rate was 1.36 percent. Only 36 percent of the women had access to health services and only 13.5 percent had access to community activities (Farías \& Billings 1993).

After more than a decade of exile, Guatemalan refugees still live in extreme poverty and life is particularly hard for women and their children. The high rates of both fertility and child mortality are related to poor health services, poor schooling and the monolingualism of mothers, which further restrains access to existing resources and services. Although women have better access to educational programs in Mexico than they had in their Guatemalan communities, basic literacy programs and those teaching Spanish still have limited coverage. Educated women who can read and speak Spanish seem more able to access health resources and help restore health or prevent diseases in their children.

Another study, conducted at "La Gloria" the largest camp in Chiapas, compared a group of severely malnourished children with a control group from the same camp. Emotional distress was significantly higher in mothers of children with second and third degree malnutrition. Symptoms associated with PTSD were reported by 71 percent of mothers of malnourished children as compared to 38 percent of mothers in the control group (Farías \& Arana 1991; Farías \& Billings 1993).

The same study revealed that mothers' interpretation of symptoms or health problems of children was markedly determined by the belief system of their indigenous culture. The community did not have a concept of malnutrition and its definition as a health problem was only later introduced by physicians, nurses, volunteers, etc., as part of their services to prevent nutrition-related health problems. In addition, help-seeking patterns were different for the two groups. Mothers of children in the control group utilized medical services more frequently than mothers of the malnourished children. However, even mothers of children in the controll group used traditional means such as spiritual cleansing, praying and herbal medicine, especially in severe cases.

\section{The School System in Chiapas, Campeche and Quintana Roo Camps}

During the first years of refuge along the Guatemalan border, emergency conditions and the need to satisfy basic requirements pushed educational and

\section{Table 2: Community Promoters and Children in Three Mexican Southeastern States}

\begin{tabular}{lcr}
\hline State & Promoters Children \\
\hline Chiapas & 51 & 1000 \\
Campeche & 17 & 500 \\
Quintana Roo & 27 & 894 \\
\hline
\end{tabular}

Source: COMADEP, May 1996.

mental health priorities aside (Santiago 1992). As conditions in the camps improved, most communities appointed educational promoters in order to teach children reading and writing skills. These educational promoters work on a volunteer basis and are often young and have not completed high school themselves. In 1985, the promoter with the highest degree of schooling was a fourth grader. Promoters started their work from scratch, surrounded by small groups of children under the shade of trees. They later received teaching materials and some training provided by UNHCR, COMAR, the Chiapas Catholic Church, the Basque government and such NGO's as the Meso-American Consultantship for Assistance and Development (COMADEP).

Nowadays, all elementary level children obtain free textbooks from the Mexican Ministry of Education. Guatemalan promoters receive periodical training by Mexican school teachers. The Mexican Institute for Adult Education (INEA) offers high school courses on television and provides information on teaching skills (COMADEP 1996). Despite scarce resources, children's education and promoters training have turned out to be wellestablished and stable projects in refugee camps. Table 2 shows the promoter and user population in the three states.

Due to the large size of single settlement populations in Quintana Roo and Campeche, it is relatively easy to sustain continued efforts and conduct follow-up studies on outcomes. Chiapas, in contrast, with a refugee population dispersed in 113 camps along mountainous areas makes such efforts extremely difficult.

The fact that most are boys, suggests that many girls drop out of school as schooling progresses. There is a culturally accepted discrimination against female education. Girls have to care for younger siblings, are given household responsibilities, become pregnant at a young age and have few personal expectancies or prospects beyond marriage and reproduction (UNHCR, May 1996).

Promoter training courses are not given credit within the Mexican educational system. Under the perspective of returning home, this makes the official recognition process of these experiences by the Guatemalan system a priority, especially on the basis of 12 years of refuge experience. During 1991, COMADEP started courses on basic teaching skills for educational promoters designed as a two-yearprogram. The project included support by teachers of public schools from the city of Toluca, Mexico State. In 1994, the same organization started an intensive professionalization program by which 132 promoters, including 32 who by now have returned to Guatemala, were to obtain an official certification as rural school teachers from the Guatemalan Ministry of Education. The program has been supported by OXFAM-Belgium and the European Commission.

Some pioneering aspects of these programs include combining such methods as personal tutoring, distance education, group sessions and 
advisory seminars. The basic program includes teaching of mathematics, language, history, human rights, gender relations, cultural identity, community development, environmental conservation, mental health and peace education.

Teams of Guatemalan teachers have developed study materials and in each of the three southwestern Mexican states there are small libraries and resident advisors. All promoters participating in this program have high school diplomas and forty new promoters are soon to enter the project. Since the 32 promoters who returned to Guatemala are pursuing further education, the program has become a bi-national effort.

\section{School Status of Guatemalan Refugee Children in Mexico City}

Recent reports by UNHCR reveal that 134 refugee children in Mexico's Federal District attend school, thirty at the preschool level, 65 at the elementary level and 39 are in high schools or technical education programs. The main obstacles to being admitted to or regularly attending school are: the lack of a birth certificate, overcrowded schools, long distances between home and school, and extreme poverty. In addition the dropout rate of girls is higher than that of boys with early pregnancy being an important factor.

\section{Alternative Psychosocial Programs}

There is an organizational network among the refugees in all camps which allows them to negotiate with governmental and international agencies. The refugee community in Mexico's southeast includes groups of organized women and young people including health promoters, educational and human rights promoters, religious counsellors, and "Permanent Committees" in charge of negotiating terms for returning to Guatemala.

Individuals working in any of these capacities are designated by their own communities. Promoters periodically attend group meetings to share information, make decisions, and organize courses and workshops. Since these groups are able to reach the whole refugee population, they are the best potential way to develop programs and implement actions.

The Federal District Committee for Assistance to Guatemalan Refugees (CDF) implemented a program named "Children and Parents" aimed at supporting development and cultural identity. Another program called "Mental Health" seeks to provide attention to, and prevention of psychological dysfunction. Both programs are based on a training model for promoters in the community (Alcón 1993; López 1994; Sáenz 1991, 1994b).

They were first started and pilot tested in Mexico City and later adopted the camps in the southeastern region. Common elements of both programs include:

1. the population's psychosocial background serves as the basic context for intervention;

2. cultural features and ethnolinguistic differences are program scope modulators;

3. teaching methods are designed to fulfill two objectives: a) training promoters assess and intervene in community problems, and b) training promoters to multiply the programs effects;

4. written materials are developed to support training.

Materials involved were i.e.: a translated version of the "South African Manual" and creating books like "From Child to Child," "From Refuge to Return," "My Homeland Book," as well as the leaflets: "Children's Feelings," and "The Parents Leaflet." Additional materials included work books for workshop replication.

\section{The Children's Program in Mexico City}

Compared with refugee adults who know why they left their country, most refugee children have been deprived of this information in order to spare them suffering, to prevent reminiscing about relatives or to avoid being discovered as illegal immigrants (López 1994). A major challenge consists in helping children to recognize their identity and to recover the thread of history that belongs to them.

In 1987, a Guatemalan teacher started the Children's Program in Mexico City and organized monthly meetings that were attended by some 30 to 40 children on a regular basis. The goal of supporting personal development and cultural identity was pursued through such recreational activities as play, drawing, gignol puppets, and show and tell conversations on Guatemalan history, geography, customs and traditions. In 1989, a psychologist joined the project as a consultant and new activities aimed at psycho-affective elaboration were added to the program.

Supporting cultural identity involves learning through active participation about Guatemalan history and ethnic diversity, geography, customs, traditions, celebrations, patriotic symbols, history of the refuge and information on returning "home."

Activities concerning the elaboration of affects include encouraging and aiding children to reconstruct their family history, to symbolically rescue their extended family, to provide new meaning to exile life, to express their fantasies about returning to Guatemala and to acknowledge their new bicultural identity. Sessions also address problems common to all children such as interaction with parents, sibling rivalry and interpersonal relations in school.

The activities concerning the elaboration of affects always involved encouraging the children's verbal expression of feelings, opinions, experiences, fantasies, complaints, etc., in a play atmosphere of complete trust and confidence. The main procedures used to conduct these sessions included expressive arts such as drawing, painting, play, dramatization of everyday situations and experiences, and puppetry.

The cumulative experience from the program allowed this group to develop the book My Homeland Book, designed as support material for elementary and high school classes. The book features games, stories and 
activities for children to actively become familiar with Guatemalan culture, history, geography and traditions. My Homeland Book has been widely distributed, i.e. in 1994, workshops on the use of My Homeland Book included 156 educational promoters wholater conducted courses including over 5,200 children.

\section{Expressive Arts}

Expressive art programs have shown to be appropriate ways to identify, analyze, communicate and effectively elaborate emotionally loaded experiences, concepts and feelings. Play and dramatization provide the individual with an opportunity to test the social perception of his/her reactions to life events, and try out different behaviours without having any negative consequences. As teaching tools, play and dramatization allow the child (or adult promoter) to listen and observe non-obtrusively at the time he/she learns and practices interactive skills (Marans, Mayes, Cicchetti \& Dahl 1991; Weschler 1987).

For example, children were asked to agree on how to represent a family and then asked to actually play the scene. If, during a particular play, a mother appeared angry and her children fought constantly, the psychologist would briefly interrupt the play and ask the children why the mother could possibly be so angry. Spontaneous responses from the children were usually along the line of the son's misbehaving. After subsequent questioning, children would provide such responses as: "she cannot make ends meet with so little money," "she is mad at her husband," "she is not living in Guatemala," "she cannot visit my grandparents," or "she ruined dinner."

At the end of a dramatization session, a period is set aside to deal with such issues as what struck the audience as relevant, how they felt about it, and how they would help those who expressed having problems. Children, for instance, were usually surprised by the fact that a mother could be angry for so many reasons not related to her children. Another verbal reaction, from one sibling to another went: "we better stop fighting because mother is in a bad mood and she might end up hitting us." This exchange denotes a change in perception and the assignment of new meaning. Children frequently learn to comprehend several alternative explanations to people's emotions and reactions and learn not to feel guilty.

Dramatization has turned out to be a particularly useful tool for persons with little or no schooling. Also, since theatre and oral history has long been a natural asset of pre-Hispanic American cultures, it was readily accepted as a way to communicate concepts and attitudes.

As a side effect the program seems to have led to a greater tolerance of parents in the sense of talking about and to increase their confidence in themselves and in their parents.

Drawing is another well established means to express and communicate ideas, feelings and emotions (Davis 1989; Shelby \& Tredinnick 1995). In the refugee context, drawing may serve to facilitate reminiscence and document traumatic experiences such as those included in the program's leaflets and handbooks.

This material may evoke memories, images and experiences in other individuals and may also help to elicit cognitive restructuring and emotional elaboration (Hernández-Guzmán \& Sánchez 1988). In Mexico training support materials that contained many children's drawings and a minimum of text were designed, developed and distributed together with a manual containing suggestions on how to use

\section{Expressive art programs have shown to be appropriate ways to identify, analyze, communicate and effectively elaborate emotionally loaded experiences, concepts and feelings.}

issues previously considered as "taboo." When parents were added to the sessions children had a chance to ask them questions as well as to be questioned themselves on a number of delicate issues. This, in turn, resolved some myths such as "they came here because his father could not find a job in Guatemala," or "they came on vacations and they liked it here so much they decided to stay," or "their father came here to study," or even "their father died in a car crash and their mother decided to move the family to Mexico." Children started talking about the war; having to escape suddenly and frequently; the family's order not to get out on the streets or to tell anyone their real names; long nights spent in fear and confusion and the permanent anxiety they and their parents experienced. Through sharing true stories children acknowledged their parents' sadness and their motivation to protect their children from painful experiences. Children started filling up cracks in their past with true stories instead of lies. This allowed them to feel better them in group work. Leaflets like "From Child to Child," and "From Refuge to Returning" are easy-to-use tools for promoter work in different languages and infuse reflection and new meaning with personal experience. Because of their contents and sequence, these materials also help refugees acknowled ge and assess their own resources, what they have learned and constructed during the refuge.

\section{The Parents' Program}

The experiences from the Children's Program led to the conviction that it was necessary to work with the parents as well. As a first consideration a space was provided to come together as a group so parents could discuss their children's education. This was to support the children's development, to facilitate better family interaction, and to strengthen the parent's cultural identity through participating with their children in cultural activities. Two mental health promoters conducted this program under the supervision of a psychologist. 
The program started with group discussions on such issues as: aggressiveness in children, punishing children, normal stages in child development, how to play with children, the refuge and its implications for children, how to handle loss, the identity of the refugee child, single parent families, widowhood, and returning to Guatemala.

Sessions usually started with the promoters proposing an issue or agenda and activities such as drawing a scene and commenting the drawing or telling an anecdote. The promoters then attempted to carefully lead the discussion toward sharing experiences and exchanging opinions concerning child rearing and child development to promote reflecting on these issues.

Other activities involved recreational and cultural activities, especially by taking advantage of holidays and anniversaries such as the "Day of the Dead." This holiday, for example, was used as an opportunity to have children and parents build toys and relive regional traditions. These experiences led to the development of a booklet describing the proceedings of the sessions and contained parents' reflections on the sessions. The booklet also includes information on child development and nutrition and has become part of the materials used in the parents workshops along the southeastern region of Mexico.

\section{Mental Health Project for Child Promoters}

In 1992 a Guatemalan mental health promoter and some NGO-volunteers started an additional program for refugee children in fifteen Chiapas and three Quintana Roo camps. Objectives, methods and support materials were essentially the same as those described above, however, a novel feature of this program involved the training of 89 child promoters. These children participated in monthly workshops conducted by adult educational promoters and later, with the support of a local promoter in the camp, children promoters taught other children the workshop's contents. So far, the method of child-to-child instruction has allowed for the multiplication of the program's objectives to 500 children in Chiapas and 200 children in Quintana Roo.

Group discussions focused on the emotional processing of the refugee experience and dealt with the following issues:

Leaving Guatemala: Each child is helped to re-establish his or her own history, reconstructing his/her experience in Mexico as well as what they know or remember from Guatemala. Children are encouraged to express their feelings, to acknowledge the value of doing so and to learn im-
Psychological problems and dreaming: Since much of what we feel gets expressed through physical discomfort and symptoms, children learn to discover this link and to use verbal expression as one way to reduce anxiety and help solve problems. When children talk about their dreams and nightmares they frequently find some relation between these and their lives, desires, concerns and discomforts. Since alcohol abuse is a severe problem in the camps, emphasis is placed on children talking about the way it affects them and their families, and reflecting on what they might reasonably do to help avoid its effects in terms of individual and family interaction.

\section{Psychosocial programs that are used to support cultural identity and enhance the development of refugee children through promoters who also act as multiplicators, are adequate and effective means to reach most refugee children.}

proved ways to handle them. Group discussions on ethnic and national issues involve the historic analysis of such events as the history of pre-Hispanic Mayas, the invasion of America by Spain, the colonial period, 500 years of Indian resistance, ethnic groups of Guatemala, biculturalism, children's rights, geography of Guatemala and Mayan religion.

Talking, listening and learning to solve problems: After learning the value of listening and talking in order to feel better, children analyze problems in terms of their components and work toward solutions to help themselves and other children. Emphasis is placed on identifying and assessing the value of the knowledge acquired in the refuge and its potential for supporting the construction of a new Guatemala.

Feelings about returning and the family: Here children learn to identify and accept their feelings, fears and expectations posed by the prospect of returning to Guatemala. They analyze the consequences of the decision to return, the implications for each member of the family and the importance of having all members of the family participate in the decision to return.
As an approach to outcome evaluation, promoters frequently report observable changes in children throughout the workshops. At the beginning children looked shy and withdrawn. Drawings included almost exclusively helicopters and massacres. As the workshops progressed, children became more confident and outgoing, participated more actively in camp life, knew more about themselves individually and as a community, regained self-esteem and helped others to regain theirs. Other effects included increased knowledge about Guatemala and their own ethnic, cultural and geographical background.

\section{Conclusions}

Psychosocial programs that are used to support cultural identity and enhance the development of refugee children through promoters who also act as multiplicators, are adequate and effective means to reach most refugee children. Programs going beyond mere therapeutic assistance and attention to symptomatic "cases" are required in order to reach community goals related to prevention and health promotion. This is especially true and

Refuge, Vol. 15, No. 5 (1996) 
important under conditions of poverty and lack of resources.

Developing culturally adequate teaching support materials is a major necessity. They secure almost instant dissemination reaching illiterate populations, especially girls and women, who often have very little access to education. The promotion of literacy and second language learning helps to improve women and children's access to further resources and services.

Increasing the educational level of women and children, strengthening their mental health, self esteem and emotional aplomb directly contributes to improved health, nutrition, psychological wellbeing and development, and functions as a preventive intervention.

Since children of unidentified refugees have much less access to opportunities and resources than those living in camps or cities, they are especially. vulnerable. Thus NGO programs that help modify these conditions are especially important.

Returning home in itself is a feargenerating perspective especially for adolescents. The development of specific programs to cope with this problem is highly needed.

Finally, since war and human rights violations cause enormous suffering and misery for refugees and especially for their children, any sensible action aimed at achieving peace and supporting human rights is bound to promote their development as human beings and dignified citizens.

\section{Notes}

1. The preparation of the final version of the present manuscript was supported, in part, by grants 4679-H9406 by the Mexican National Council for Science and Technology (CONACYT), and IN304494 by UNAM's Research Support Program (PAPIIT). The authors are gratefully indebted to professors Laura HernándezGuzmán and Lucy Reidl, for their comments and feedback to the manuscript. Correspondence should be addressed to either author at: johannes @servidor.unam.mx or indas@servidor. unam.mx

\section{References}

Aguayo, S., H. Christensen, L. O'Dogherty, L., and S. Varesse. 1989. Los Refugiados Guatemaltecos en Campeche y Quintana Roo: Condiciones Sociales y Culturales en Mexico. México: El Colegio de México.

Alcón, I. 1993. "Proyecto de Salud Mental para Promotores Infantiles." Nite-Lob. Organo Informativo de la Red Regional de Salud Mental. México y Centroamérica. 2(julio-diciembre), 29-32. San Salvador: El Salvador.

Apfel, R., and B. Simon. 1992. Psychological and Psychosocial Aspects of Children in War and Situations of Violence: Bibliography. Cambridge: Mass. Harvard Medical School.

Bottinelli, C., I. Maldonado, E. Troya, P. Herrera, and C. Rodriguez. 1990. Psychological Impacts of Exile. Salvadoran and Guatemalan Families in Mexico. Washington, D.C.: Center for Immigration Policy and Refugee Assistance, Georgetown University.

Comité del D.F. de Ayuda a Refugiados Guatemaltecos. 1990. Counseling Manual, Versión Castellana, CDFARG, del original por OASSSA, South Africa.

Davis, C. B. 1989. “The Use of Art Therapy and Group Process with Grieving Children, Special Issue: The Death of a Child: III." Issues in Comprehensive Pediatric Nursing 12(4), 269-80.

Del Huerto, A. M. 1986. Problemática del Niño Centroamericano Refugiado en México. Mexico: Licentiate Thesis, School of Psychology, UNAM.

Deutsch, M., M. Hoffnung, D. Speyer, C. Varela, and M. Viriar. 1991. "El Silencio y el secreto en el régimen del terror." Proceedings of the III Conferencia Internacional: Salud, Represión Politica y Derechos Humanos, 61-65, Santiago de Chiles.

Didier, B. 1985. Refugiados Guatemaltecos México: COMAR-Praxis.

Doná, G. 1993. “Guatemalan Refugee Women: Cultural Issues in Repatriation and Settlement." Paper read at the conference on Gender Issues and Refugees: Development Implications.

Espino, C. 1991. "Trauma and Adaptation: The Case of Central American Children." In Refugee Children: Theory, Research and Services edited by F. Ahearn and J. A they. Baltimore: The Johns Hopkins University Press.

European Commission. 1995. Assistance to Refugees, Displaced Persons and Returnees. México: E.C.
Falla, R. 1983. Voices of the Survivors: The Massacre at Finca San Francisco, Guatemala. Cambridge, Mass: Cultural Survival

Farías, P., and M. Arana. 1991. "Aspectos psicosociales de la desnutrición infantil entre los refugiados guatemaltecos en Chiapas." Paper read at the Segundo Congreso Nacional de Salud Pública, Cuernavaca, México.

Farías, P. 1992. "El modelo biomédico frente a la tradición indígena Maya. El caso de los refugiados guatemaltecos en Chiapas." Paper read at the VI Coloquio: Magia y Medicina, México.

Farías, P., and D. Billings. 1993. "The Impact of Refugee Women's Social Status on Psychosocial Health, Child Mortality and Malnutrition." Paper read at the Congreso Internacional de Antropología y Ciencias Etnológicas: Desplazamiento, La Mujer y la Crisis Global, México.

Guatemala Health Rights Support Project. 1992. Guatemalan Refugees in México. Unfinished Stories. Guatemala Health Rights Support Project, Washington, D.C. Issue Brief, Summer 1992.

Harrington, B. 1994. Uprising, A Story of Origins: Chronicle of a Relationship Created Over Time. Comité del D.F. de Ayuda a Refugiados Guatemaltecos. México, D.F.

Hernández-Guzmán, L.. and L. Sánchez. 1988. "Evaluación experimental del manual La Salud Mental de Menores en Situaciones de Desastre." Revista Mexicana de Psicologia 7(1) 88-92.

Kinzie, D., and W. Sack. 1991. "Severely Traumatized Cambodian Children: Research Findings and Clinical Implications." In Refugee Children: Theory, Research, and Services, edited by F. Ahearn and J. Athely. Baltimore: The Johns Hopkins University Press.

Kordon, D., L. Edelman, D. Lagos, E. Nicoleti, and R. C. Bozzolo. 1988. Psychological Effects of Political Repression. Buenos Aires: Planeta.

López, A., and I. Sáenz. 1991. De Niño a Niño. Mexico: Comité del D.F. de Ayuda a Refugiados Guatemaltecos.

López, A. 1992. Del Refugioal Retorno. México: Comité del D.F. de Ayuda a Refugiados Guatemaltecos.

López, A. 1994. "Niños y padres refugiados: Apoyando su identidad y relaciones." Crónica de una relación construida. México: Comité del D.F. de Ayuda a Refugiados Guatemaltecos.

López, A., I. Sáenz, M. Comparini, and C. Mier. 1994. Mi Libro Patrio. Mexico: Comité del D.F. de Ayuda a Refugiados Guatemaltecos. 
Lykes, B. 1994. "Terror, Silencing and Children: International Multidisciplinary Collaboration with Guatemalan Maya Communities." Social Science and Medicine 38,(4),543-52.

Manz, B.1987. Refugees ofa Hidden War: Aftermath of Counterinsurgency in Guatemala. New York: SUNY.

McCallin, M. 1991. "The Impact of Current and Traumatic Stressors on the Psychological Well-Being of Refugee Communi ties." In The Psychological Well-Being of Refugee Children: Research, Practice and Policy Issues, edited by M. McCallin. Geneva: International Child Bureau.

Mama Maquin. 1994. De Refugiadas a Retornadas. Memorial de Experiencias Organizativas de las Mujeres Refugiadas en Chiapas. O.M.R.G., Chiapas, Mexico: e.IAM.

Marans, S., L. Mayes, D. Cicchetti, K. Dahl, et al. 1991. "The Child-Psychoanalytic Play Interview: A Technique for Studying Thematic Content." Journal of the American Psychoanalytic Association 39(4), 101536

Melville, M., and B. Lykes. 1992. "GuatemaIan India Children and the Sociocultural Effects of Government-Sponsored Terrorism." Social Science and Medicine, 34(5), 533-48.

Metraux, J. c. 1989. Los Ninos Vfctimas de la Guerra: Manual de Atencion Psicosocial para Promotores. Managua, Nicaragua: Ciencias Sociales.

Metraux, J. c. 1990. El Nino, la Familia y la Comunidad: Manual de Atencion Psicosocial para Promotores. Managua, Nicaragua: Ciencias Sociales.

Metraux, J.e., and A. Aviles. 1991. "Training Techniques of Non-Professionals: A Nicaraguan Preventive and Primary Care Programme in Mental Health." In The Psychological Well-Being of Refugee Children: Research, Practice, and Policy Issues, edited by M. McCallin. Geneva: Issues, tional Catholic Child Bureau.

Miller, K., and D. Billings. 1994. "Playing to Grow: A Primary Mental Health Intervention with Guatemalan Refugee Children." American Journal of Orthopsychiatry 64(3), 346-56.

O'Dogherty, L. 1991. Central American Refugees in Mexico City: Uprooted and Silenced. Washington, D.C.: Georgetown University.

Ramirez, G. 1992. "Pluridentidades y derechos del nino." In Una Decada de Refugio en Mexico, edited by G. Refugio en Mexico,

Saenz, I. 1991. "Formaci6n de promotoras guatemaltecas de salud mental refugiadas en Mexico." In Proceedings of the III Conferencia Internacional: Sa Iud, Represion PoUtica y Derechos Humanos, 155-59. Santiago de Chile.

Saenz, I. 1992/1993. "Listening to the Refugees: Guatemalans in Mexico." Links 9(5), 24-25.

Saenz, I. 1994a. "La Atenci6n y Prevenci6n de la Salud Mental de los Refugiados Guatemaltecos en Mexico." In Experiencias del Refugio Centroamericano: Perspectivas de Salud Mental y Psicosocial, edited by P. J. Farias and R. Miranda. Mexico: Colegio de la Frontera Sur.

Saenz, I. 1994b. Un Modelo Para el Apoyo de la Salud Mental de los Refugiados Guatemaltecos en el Sureste de Mexico, a Traves de la Capacitacion a los Promotores de la Traves de la Capacitacion a los Promotores de la
Comunidad. Masters Thesis, Mexico: Comunidad. Masters Thesis,
Facultad de Psicologia, UNAM.

Salvad6, L. 1988. The Other Refugees: A Study of Non recognized Guatemalan Refugees in Chiapas, Mexico. Washington, D.C: Georgetown University.

Santiago, M. E. 1992. "Situaci6n Educativa de Poblaci6n Guatemalteca Refugiada en Mexico." In Una Decada de Refugio en Mexico, edited byG. Freyermuth. Mexico: Casa Chata.

Shelby,J. S., and M. G. Tredinnick.1995. "Crisis Intervention with Survivors of Natural Disaster: Lessons from Hurricane Andrew." Journal of Counselling and Development 7(5), 491-97 Simon, J. M. 1987. Guatemala, Eternal Spring, Eternal Tyranny. New York: Norton. ummerfield, D. 1991. "Psychosocial Effects of Conflict in the Third World." Develop ment in Practice, an OXFAM Journal 1(3), 159-73.

Venet, F., and M. A. Castillo. 1996 "Inmigraci6n y Politicas Migratorias en Mexico." Paper read at the Foro Sobre Migraci6n Regional: Mexico, Centroamerica y Estados Unidos, Mexico, D.F.

Weschler, S. 1987. "Efeitos do treinamento em criatividade em crian as bemdotadas e regulares." Arquivos Brasileiros de regulares." Arquivos Psicologfa 39(4), 95-110

Westermeyer, J. 1989. "Paranoid Symptoms and Disorders among 100 Hmong Refugees: A Longitudinal Study." Acto Psychiatrica Scandinavica 80(1),47-59.

Westermeyer,J.,M. Bouafuely,J. Neider, and A. Callies. 1989. "Somatization among Refugees: An Epidemiologic Study." Psychosomatics 30(1), 34-35.

Zur, J. (1993). Violent Memories: Memories Quiche, War, Widows \& Northwest Highland. $\mathrm{PhD}$ dissertation, Social Anthropology. London School of Economics, University of London. 0 ominattb for tbt 1991 QtbomaiS \& \%njhtietldJJti t. to be atDarbeb in

6ummer lip t $\{$ Je Jnternahonal

JlUlJtation \&emon of tbt a:mmcan \&otiological a:iSiSotiatton

\section{PATHS To EQUITY}

Cultural, Linguistic, and Racial

Diversity in Canadian Ear'ly

\section{Childhood Education}

by Judith K. Bernhard, Marie

Louise Lefebvre, Gyda Chud and

Rika lAnge Toronto: York Lanes

Press ISBN 1-55014-277-1; 112

$\mathrm{pp}$,

size 8.5xll; \$18.95

Paths to Equity is based on an extensive nationwide study of 77 childcare centres in Montreal, Toronto, and Vancouver on the cultural, linguistic, and racial diversity in Canadian Early Childhood Education (BCE). The report presents the results this study on how the ECE system is responding to the increasing diyersityof contemporary Canadian society.

A fully one third of teachers interviewed in this study responded, at the time of graduation fromECE programs, did not feel that they were well pteparedto work effectively with children and parents from diverse backgrounds. In this ground-breaking study, the authors have addressed teachers' views 011 $\operatorname{diV} \sim$ (\$ityil1the educationprograIQS; parents difficulties in collaborating within the current education system; teachers' difficulties in understanding many "ethnic" parents; desire of many pareJ)fS for be ter conununication with staff,preferably-in their own languages, and for more information about their individual children. and chances for

effective input; and the evidence of some continuing problems with racism,il:respective of the good intentions of centre staff.

Paths to Equity will be of interest to ECE faculty, policy makers, centre supervisors and staff and others interested in the inclusion of diversity content in professional education programs. 


\begin{tabular}{l} 
From Being \\
Uprooted to \\
Surviving: \\
Resettlement of \\
Vietnamese-Chinese \\
"Boat People" in \\
Montreal, 1980-1990 \\
By Lawrence Lam \\
Toronto: York Lanes Press \\
ISBN 1-55014-296-8 \\
200 pages, indexed; \$18.95 \\
The saga of the "boat people" is a \\
dramatic story, a story of one of \\
the largest refugee movements in \\
recentyears. Canada played asig- \\
nificantrolein the resettlement of \\
these refugees in bringing them \\
to Canada where they could start \\
anew.From Being Uprooted to Sur- \\
viving by Professor Lam, is based \\
on ethnographic data of a sample \\
of Vietnamese-Chinese accepted \\
for resettlement in Montreal in \\
1979 and 1980, who were \\
reinterviewed in 1984 to 1985and \\
again in 1990 to 1991, this book \\
provides a longitudinal account \\
of their experience of resettlement \\
in Canada. This experience has \\
been marked bysuccessivestages \\
of their struggle to overcome \\
structural barriers and to negoti- \\
ate a meaningful nichein Canada. \\
Contents: Preface, The Boat Peo- \\
plePhenomenon, Resettlement- \\
Issues and Perspectives, The Vi- \\
etnamese-ChineseRefugees, Exo- \\
dus and Transition, Resettlement \\
Process-The First Three Years, \\
Resettlement-Beyond the First \\
Three Years, Conclusion. \\
Please send your orders to: \\
York Lanes Press \\
Centre for Refugee Studies \\
North York ON M3J 1P \\
\hline
\end{tabular}

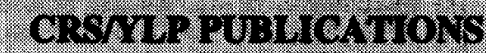 Boors}

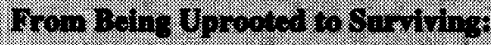

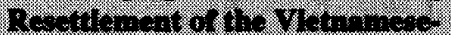
2.

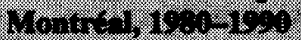

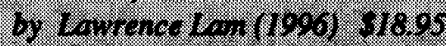

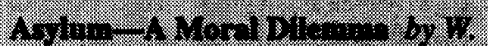

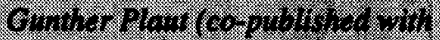

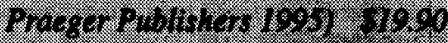

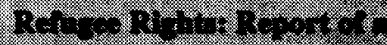
$0.0,0.0,0,0,0,4,0$

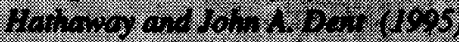

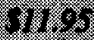

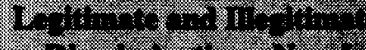

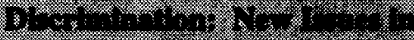

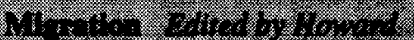

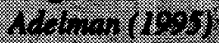

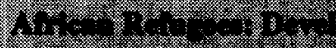

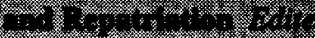

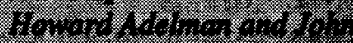

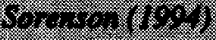

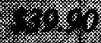

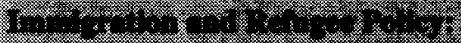

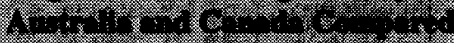

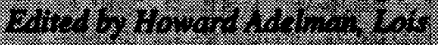
Tourar.

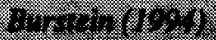

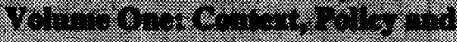
T.

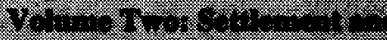
13. $-4.5: 5$

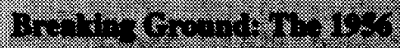

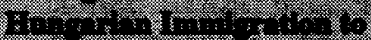

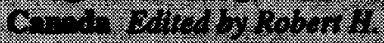

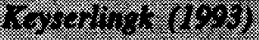

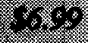

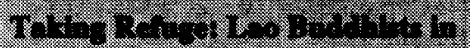

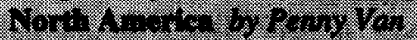
$28(8,1(1882)$

$0,0,80$

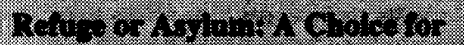

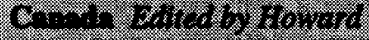

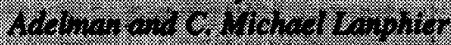

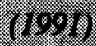

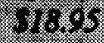

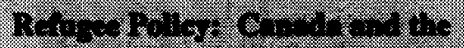

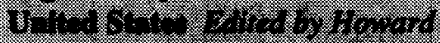

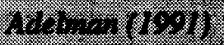
4.095

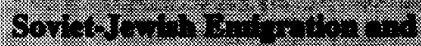

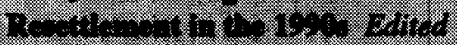

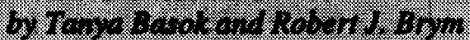
$(4,3)$

1.96

\section{PUS $1155^{\circ}$}

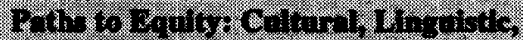

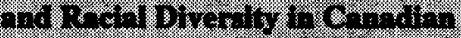

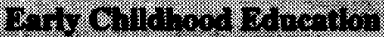

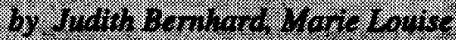

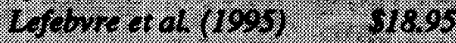

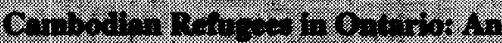

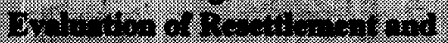

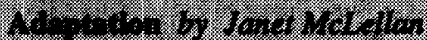
$\left(3^{2}\right)$

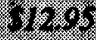

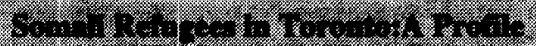

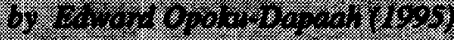
. 13,5

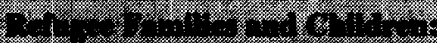

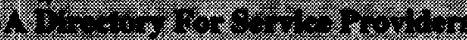

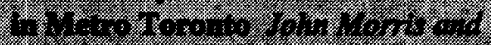

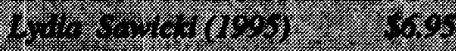

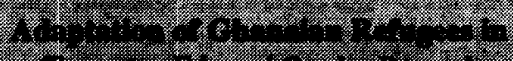

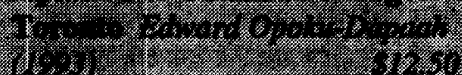

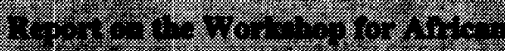
40

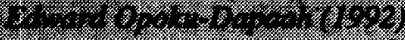
. 13

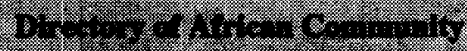

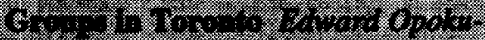

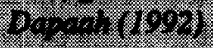
1,150

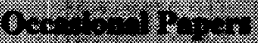

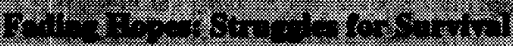

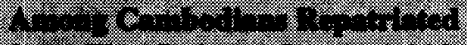

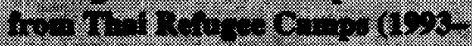

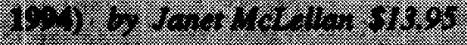

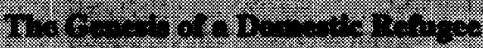

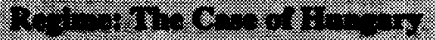

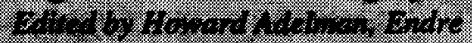

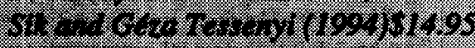

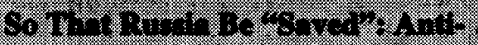

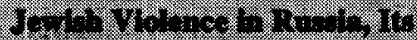

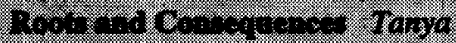

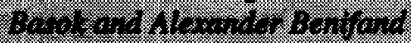
$(4,8)$ 3.958

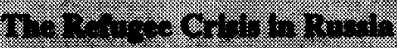

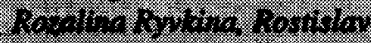

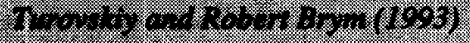
$30 \%$

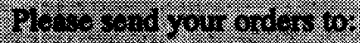

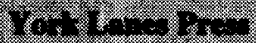

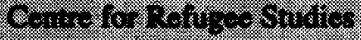

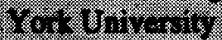

Heg. 


\section{BackIssues of Refuge}

The following is a list of general andtbematic issues of Refuge-Canada;s periodical on refugees. 1, Environmental Refugees, Vol. 12, No. I, June 1992.

2. Discussion oflJnmigration Bill C-86, V01.12, No.2, July/(Aug.) 1992.

3. General IssuelRefugee Sponsorship, VoU2, No.3, Sept. 1'992.

4. Eastern European Refugees, Vo1.12, No.4, Oct. 1992.

5. The Tragedy of SomaUa, V 01.12, No.5, Nov.lDec. 1992.

6. TbeReview of Rejected Refugee Claims inCanada, Vo1.12, No.6, Jan. 1993. 7. Russia and Central Eurasia; V 01.12, No. 7,'FebrUary 1993.

8. Africa Issue: Repatriation, V 01.12, No., 8, Marcb, 993.

9. GeneraUssuelGlobalization, Vo1.13,No. J, Apnl,1993.

10., <Russia and Central Eurasia, V01.13, No.2, Mayf993.

11. spec:: ${ }^{H "}$ ar: $\sim$ e on\$ri an a,YoLI3,No. 3, Ifine"i 3.

12. GeliaerIssues,iilid ',Ritugee Law, VoL 13, No. 4;]uly/Aug. 1993.

13. Southeast!siattRefugees, "01.13, No.5, Sept/11993.

.14. Moz i an:-Re Ugees, VoL 13, No. 6, Oetobed9 3.

15. Russia: and Central Eurasia, V 01.13, No.7, Nov.lDee. 1993.

16. General Issue/Sudan, Vol.13, No.8, January 1994.

17. Integration of Refugees-The Canadiau Experience Voll':;, No.9, Feb. 1994.

18. Refugees and Peace in Central America, Vo1.13, No. 1O,March 1994.

19. 89m of Africa, Vo1l4, No.1, April 1994

20. The Russian Fetieration..Yot.14, No.2, May 1994.

21. The Former Yugoslavia, Voll4, No.3, june/July 1994.

22. General IssueIIRB and Rebuilding Trust/

Tamil ImlDigrantsin Canada, Vol.14, No.4, Aug.lSept, 1994.

23. Rwandan Crisis, Vol.14, No.5, October 1994.

24.aefugee Resettlement in Israel,Vol.14, No.6, Nov. 1994.

25. Refugee Women Part 1: Issues. V01.14, No.7, Dec. 1994.

26. Refugee Women-Part 2: Case Studies, Vo1.14, No. 8, Ian. 1995.

27. The Safe Third Country Concept, Vol.14, No.9, February 1995.

28. Special Issue on Checbnya, VoL14. No. 10, March 1995.

29. Reformulation oUnternationalRefugee Law, Vo1.15, No.1, 1996.

30. Environment, Development a d Refugees, V01.15, No.2, 1996.

31. International Intervention in Refngee Crises, Vol.15, No. 3,1996.

32. Early Warning on Humanitarian Crises, Vo1.15, No.4, 1996.

33. Special Issue on Child Refugees, Vo1.15, No.5, 1996.

Single copy: Vol 12, 13 \& 14-\$6.50; Vol 15-\$10. 10\% discount on 3-9 issues (copies); $20 \%$ discount on 10 issues (copies) or more. Special discounts are available for students and exclusively volunteer run NGOs. P. O. accepted. Please send your orders to:

York Lanes Press, Suite 351, York Lanes, Centre for Refugee Studies, York University, North York, Ontario Canada M3J 1P3.

Fax: (416) 736-5837. Internet: refuge@yorku.ca

Refuge, Vol. 15, No.5 (1996)

\section{Asylum: A Moral Dilemma}

By W. Gunther Plaut

Toronto: York Lanes Press

ISBN 1-55014-239-9

192 pages, indexed; $\$ 19.90$

Every year the refugee landscape changes, but only in that more problems are added, fewer are solved, and all become constantly more urgent. Fuelled by the explosion of the world's population, the quest for asylum is one of the most pressing problems of our age. Refugee-receiving nations-located frequently, but by no means exclusively, in the Western worldhave to respond to masses of humanity searching for new livable homes. Human compassion for these refugees can be found everywhere, but so can xenophobia and the desire to preserve one's nation, economic well being, and cultural integrity. The clash between these impulses represents one of the great dilemmas of our time and is the subject of Plaut's study. In exploring it, he provides a farranging inquiry into the human condition.

The book presents political, ethnic, philosophical, religious, and sociological arguments, and deals with some of the most troublesome and heartbreaking conflicts in the news.

Contents: The Issues; Questions Without Answers; Definitions; Religion, Natural Law, and Hospitality; A Look -at History; Some Ethical Questions; Through the Lens of Sociobiology; Community and Individual; Contended Rights: To Leave, Return, Remain;

The Practice; Refugees in Africa; Four Asian Lands; Glimpses of Europe and Central America; The North American Experience; The Sanctuary Movement; A Final Look; Bibliography; Index. Asylum-A Moral Dilemma is simultaneously published in the United States by Praeger Publishers, and in Canada by York Lanes Press. 


\section{Refuge \\ Centre for Refugee Studies Suite 351, York Lanes York University. \\ 4700 Keele Street, North York \\ Ontario, Canada M3J 1P3 \\ Phone: (416) 736-5843 \\ Fax: (416) 736-5837 \\ Internet: refuge@yorku.ca}

\section{Summer Toromto - June 11-19, 19:}

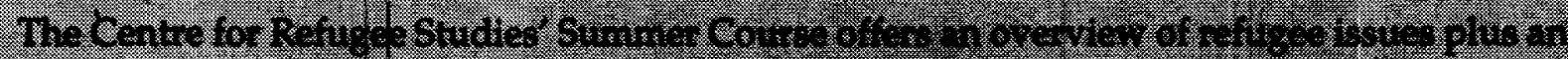

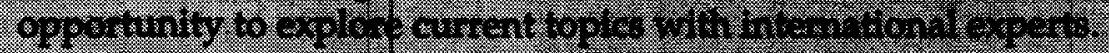

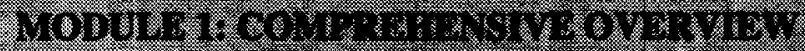

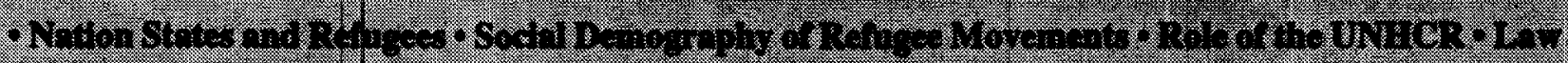

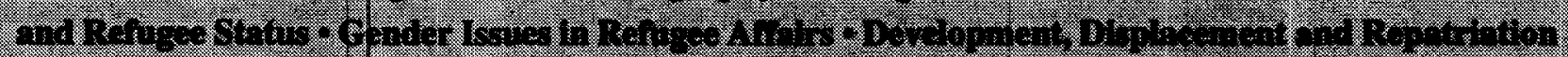

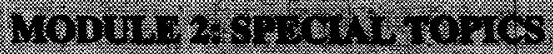

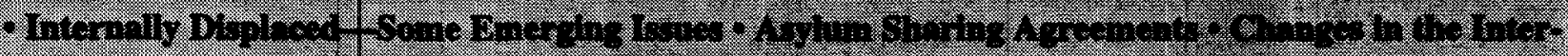
Amer

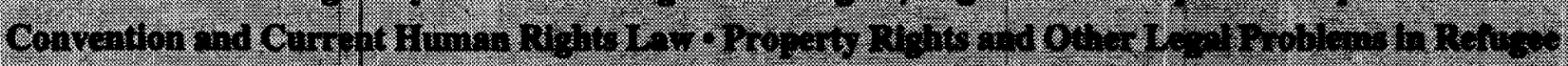

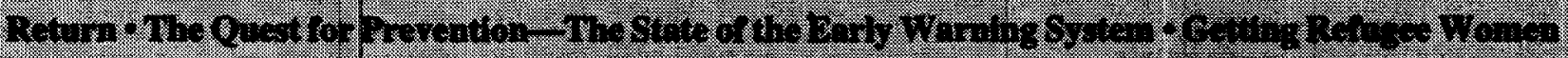

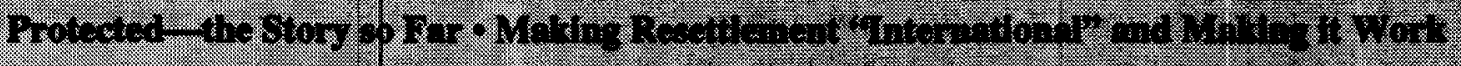

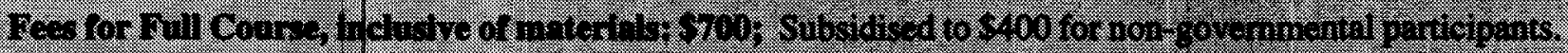

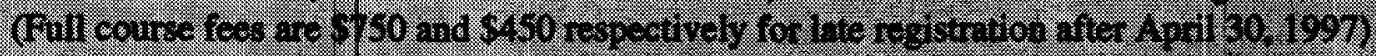

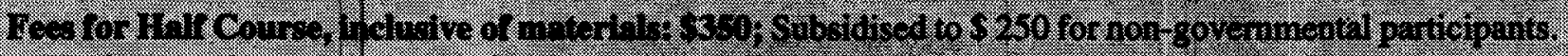

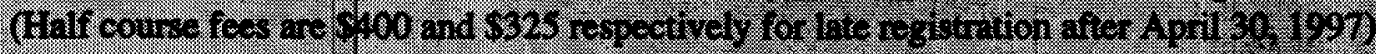

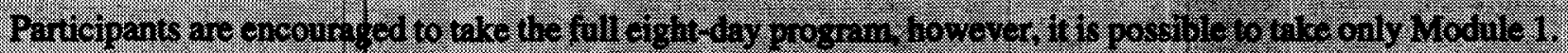

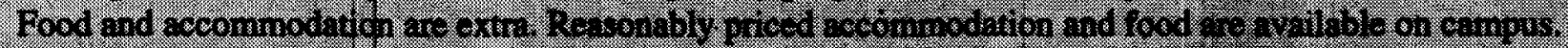

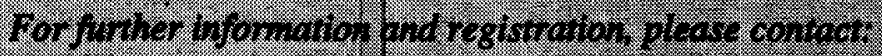

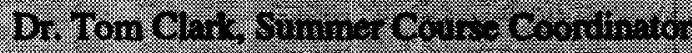

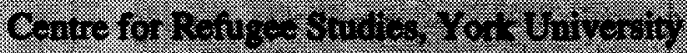

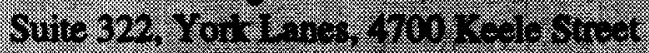

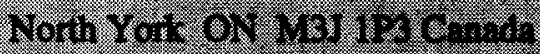

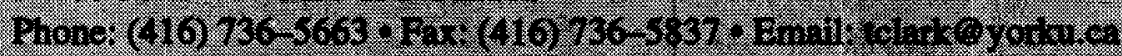

